\title{
China Challenges Global Capitalism
}

\author{
VLADO VIVODA*
}

\begin{abstract}
This paper establishes a novel understanding of the nature and implications of China's rise. By borrowing Robert Gilpin's concept of suboptimization, it is argued that China is the leader in a non-Western subgroup's suboptimization strategy which undermines the Western-dominated neoliberal capitalist system, or the Washington Consensus, and liberal democratic values, taken as gospel by Western economists, governments and industry for the past 30 years. While China and other non-Western states are a part of this system, a consequence of their actions within the system, and particularly in the international energy markets, is that they are increasing their relative gains at the expense of the larger group. China-led subgroup's suboptimization strategy may result in direct competition between the predominant neoliberal Western paradigm, which is synonymous with globalization, and which has entered into a structural crisis, and the emerging non-Western economic and political capitalist model.
\end{abstract}

\section{introduction}

\footnotetext{
* Vlado Vivoda is Research Associate at the University of South Australia, Adelaide. He has

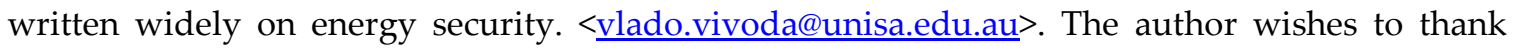
Andrew O'Neil, Gerry Groot, James Manicom, Alex Stephens, and Richard Leaver for their feedback on previous drafts.
} 
China's rise as a major power is undeniable and uncontested (Kristof 1993: 5974). However, this agreement on China's rise is in complete contrast to academic understandings of its nature and implications. Scholars disagree on the nature of China's rise; on whether a rising China is multilateral, status quo power, or a unilateral revisionist state; on whether China is balancing, or challenging, the predominant US power in the region and around the world; and on the implications of China's rise for regional and global security, and its relationship with the US. The aim of this paper is not to provide a definitive answer to any of these questions, but to establish an alternative and novel understanding of the nature and implications of China's rise. By borrowing Robert Gilpin's concept of suboptimization, this paper proposes that China is the leader in a non-Western subgroup's suboptimization strategy which is undermining the Westerndominated neoliberal capitalist system, or the Washington Consensus, and liberal democratic values, taken as gospel by Western economists, governments and industry for the past 30 years. While China and other non-Western states are a part of this system, a consequence of their actions within the system is that they are increasing their relative gains at the expense of the larger group. Although the focus here is on China, examples are often drawn from other non-Western states.

In what ways does the China-led subgroup suboptimize against the Westerndominated capitalist system? There are two major ways in which suboptimization takes place and at the same time, there are numerous implications caused by this strategy. Firstly, it is evident through China's neomercantilist strategy of competing for access to, and control of, hydrocarbon resources, which challenges the rules-based international order for trade and investment, and which is accompanied by the return of resource nationalism in energy exporting states. Secondly, it is obvious through the general rise of stateowned enterprises (SOEs) in China, but also in many non-Western countries, which challenge the future dominance of the private sector and the future of globalization. With regards to implications, China's neo-mercantilism in the energy markets, and resource nationalism in energy exporting states re-introduce energy security concerns for Western countries, which were ever so present in the 1970s, and are causing a major crisis for Western international oil companies (IOCs). The rise of SOEs in China and other non-Western countries challenges the globalization theory, which was taken for granted in the 1990s. Moreover, non-Western suboptimization may be a signal that we have entered the genesis of an age of long transition from, or 'bifurcation' of, the Western-dominated capitalist system, which is facing a structural crisis (Wallerstein 1979, 1995; Arrighi 1994). While all of these trends and implications will be examined in 
much detail below, it is firstly essential to elaborate on inadequacies stemming from scholarly perceptions of the nature and implications of China's rise, and on suboptimization as an alternative and more useful approach.

perceptions of the nature and implications of China's rise

There are three sides in the scholarly disagreement about the nature and implications of China's rise. Firstly, there are those who argue that despite the rhetoric of China's 'peaceful rise', the $\mathrm{CCP}^{\prime}$ 's global goals are "reordering the world system and dominating Asia." According to this school, China seeks to create "a new world order", foundations of which clearly clash with prevailing international norms (Gilley 2004: 51). Since China intends to become a great power, this would entail regional pre-eminence in East Asia, most certainly at the expense of the now-dominant United States (Cohen 2006: 129). Many therefore argue that China is a revisionist state, committed to regional hegemony, global multipolarity, and thus, that it is, or soon will be, balancing the US predominance in East Asia and/or globally. Some of these scholars claim that China is 'hard balancing' against the US power, and they often argue that China's military modernization since the mid-1990s has been aimed at developing capabilities to deter or slow the application of US military power in the region (Shambaugh 2000; Feigenbaum 2001; Ross 2004). Others argue that China's balancing is more subtle, or soft, evident in China's usage of soft power resources, formation of informal alliances, and voting and veto behaviour in international organizations (Paul 2004; Pape 2005; Walt 2005; Art 2005/06; Gill and Huang 2006; Kurlantzik 2007). Finally, some hardliners who can be categorized as 'China threat' scholars have even suggested that China and the US are on the collision for conflict (Song et al 1996; Calder 1996; Bernstein and Munro 1997; Qiao et al 1999; Timperlake and Triplett 1999; Gertz 2000; Mearsheimer 2001). [1]

Secondly, there are those who argue that Beijing is committed to a 'peaceful rise' (Zheng 2003; Sutter 2004; Guo 2006). In light with this foreign policy doctrine, other Asian states and the United States should not regard China's economic and military rise as a threat to regional and global peace and stability, but as an opportunity, in particular with regards to economy. Many of these scholars also assume China to be a status quo power, a responsible member of the international community, and committed to multilateralism, international cooperation and avoidance of confrontation with the US and other regional powers (Johnston 2003; Goldstein 2005; Bergsten et al 2006). They draw support from China's increasing participation in international institutions; compliance 
with international norms such as sovereignty, free trade, nonproliferation and arms control, human rights; behaviour toward the 'rules of the game'; and nonrevisionist preferences (Johnston 2003). Despite various dramatic episodes in the relationship, such as the US granting of a visa in 1995 to the President of Taiwan, the 1996 Taiwan Strait crisis, NATO's May 1999 bombing of the Chinese embassy in Belgrade, and the April 2001 plane collision, Sino-American relations are seen as stable, driven by complex interdependence, and are "characterized by substantial cooperation on bilateral, regional, and global issues" (Shambaugh 2004/05: 97). Thus, various scholars argue that China is 'bandwagoning', and not hard balancing or soft balancing against the US power in East Asia, or globally (Kapstein and Mastanduno 1999; Wohlforth 1999; Ikenberry 2002; Van Ness 2002; Johnston 2003; Brooks and Wohlforth 2005; Lieber and Alexander 2005; Hays Gries 2005; Lieber and Alexander 2005/06). Arguably, China accepts American presence in East Asia as it provides regional stability and security, particularly as it relates to its concerns of resurgent Japanese militarism, and US hegemony and unipolarity in general (Johnston 2003; Wang 2005; Yahuda 2005). A larger US presence in East Asia allows the basis for China's peaceful rise, as otherwise, regional neighbours would be far more wary of embracing a rapidly growing China. Despite China's increasing military development and double-digit growth in military budget in the last two decades, the main issue at stake for China is Taiwan, essentially a domestic issue, and not the US strategic presence in the region. Moreover, this benign school argues that China is not trying as hard as it might to construct anti-US alliances or undermine US alliances globally and regionally (Johnston 2003: 38-9), and that in future, when and if China and the US reach economic and/or military parity, the power transition would be peaceful (Zhu 2006).

Finally, there is the group which can be characterized as the 'fence-sitters' who perceive the nature of Beijing's rise as accommodating with the US-dominated global order, but which at the same time contains an important 'hedging' element, or insurance policy, through which China seeks to secure its future (Goh 2005; Foot 2006). The balancing-bandwagoning dichotomy is described to be "too limited to capture the range of choices" for a state (Acharya 2003/04: 152). Since China's strategy cannot be characterized either as bandwagoning or softbalancing, Rosemary Foot interpreted this strategy as China's 'softbandwagoning' with the United States (Foot 2006: 88-9). Various other scholars belong to this category. For example, Peter Hays Gries characterized China's strategy as "bargaining, binding, and buffering", while Avery Goldstein describes it as a 'neo-Bismarckian' strategy of transition which "aims to avoid the provocative consequences of the more straightforward hegemonic and balancing 
strategies" (Goldstein 2005; Hays Gries 2005; Sutter 2005; Medeiros 2005/06; Christensen 2006).

The main focus of the above debate is on the concept of balance of power, which due to its focus on geopolitical and military, and not economic issues, is of very limited utility in the contemporary world, and was much more useful during the Cold War. It is in China's long-term interest to pursue a cooperative strategy with the rest of the world and the US in particular as such strategy enables China to maintain its rapid economic growth. Beijing seeks continued economic growth, because rising living standards provide the CCP's only claim to legitimacy: "Economic growth has become the central justification for continued CCP rule since Mao's death ... it determines the future of the entire political system" (Gilley 2004: 37). Thus, since rapid economic growth is crucial for maintaining the domestic regime stability, domestic interests are more important than foreign policy interests (Swaine 2005: 23). For example, $\mathrm{Ng}$ argues that "holding on to state power has been and continues to be the main objective of the CCP" (Ng 2006: 44). Given that economic growth considerations, and not strategic balancing against US power, dominate China's foreign policy, applying an alternative conceptualization, suboptimization, which is based primarily on economic issues, is a more effective way to grasp the nature and implications of China's rise.

suboptimization

Robert Gilpin suggests that as the scale of a state, empire, or a market economy increases, subgroups frequently suboptimize, or increase their own gains at the expense of the larger group or the system as a whole. Gilpin defines this suboptimization as "the effort of a subgroup to increase its relative gains at the expense of the larger group" (Gilpin 1981: 149). Suboptimization is not a conscious and explicit strategy, but an unintended consequence of subgroup's actions. In the modern world, Gilpin argues, suboptimization has frequently taken the form of economic nationalism as developing states seek to reduce their dependence on more advanced economies (Gilpin 1981: 150). It is important to note that suboptimization is not yet another form of soft balancing. Pape describes contemporary soft balancing as "actions that do not directly challenge U.S. military preponderance but that use nonmilitary tools to delay, frustrate, and undermine aggressive unilateral U.S. military policies" (Pape 2005: 11). Although suboptimizing subgroups do not directly challenge a hegemon's military preponderance and they do use nonmilitary tools, these tools are not only used to delay, frustrate, and undermine aggressive unilateral military policies of the 
hegemon, but to increase the subgroup's relative gains at the expense of the larger group in general, in this case, the Western-dominated capitalist system. This may involve frustrating the hegemon's policies in general, but not exclusively in the military sphere. Thus, soft balancing is a subordinate category to suboptimization.

Having defined suboptimization, it is necessary to identify countries which belong to the aforementioned subgroup and to elaborate on what is considered to be the larger group. The larger group is the Western-dominated capitalist system, or America's liberal hegemony, to borrow Ikenberry's conceptualization (Ikenberry 1999: 23-8). The rules of this hegemonic system have been set by the Organization of Economic Cooperation and Development (OECD) countries, and in particular by the United States through Washington-based institutions, such as the International Monetary Fund (IMF), and the World Bank. This hegemonic system has been based on neoliberalism and 'Washington Consensus' - open markets ('free' trade), privatization, deregulation, trade and financial liberalization, individualization of welfare, and constraining the role of the state - and liberal democratic values. In the latter part of the twentieth century, a system based on neoliberalism clearly favoured rich, Western countries, as it opened up developing countries to investment from large multinational corporations (MNCs) and their wealthy owners in advanced Western economies.

With regards to the subgroup, there are various countries which aim to increase their own gains at the expense of the larger group to which they belong, the Western-dominated capitalist system, and none of them are Western. These are mainly developing countries, such as China, and possibly even greater China, including Southeast Asia, and many energy producing and exporting countries, such as Russia, Iran, and Venezuela. Most of these countries are not liberal democracies and are authoritarian, and close Sino-Russian relationship, which is examined below, forms an axis of this informal subgroup.

China and Russia, both non-Western countries, and which are not liberal democracies, are becoming increasingly close and are both uncooperative with the United States on important issues. Close Sino-Russian relations are evident in large-scale Russian arms sales and nuclear technology supplies to China (Blagov 2003), and also in the final resolution of long-standing border issues, unprecedented level of cooperation, joint military exercises, increasing energy links, and the rapid increase in bilateral trade. In recent years Moscow has worked assiduously to establish a new sphere of influence in Central Asia and former Soviet Union in general, using regional autocrats' interest in resisting US 
pressure to democratize. Meanwhile, China has been trying to avoid 'encirclement' by US forces and limiting its reliance on maritime supplies, to maximize pressure on America (Leverett and Noël 2006: 65; Trenin 2006: 87-96). Therefore, Russia and China have found a common cause in limiting US influence in Central Asia (Trenin 2003: 119-31; Wesley 2005: 10), and their 2001 establishment of Shanghai Cooperation Organization (SCO) together with four Central Asian states may serve to achieve that goal. In addition, together with Beijing, and against Washington, Moscow opposed the 1999 NATO's Kosovo campaign, the 2003 US-led invasion of Iraq, and any comprehensive sanctions or other cause of action to be carried out against Tehran for its alleged noncompliance with the Nuclear Non-proliferation Treaty (NPT). It is also important to keep in mind that Iran is an SCO observer, with the possibility of joining the organization in future (Keefer Douglas et al 2006: 10-4). In addition to opposing US interventionism, and its influence in Central Asia, Moscow and Beijing held common views in opposing both Washington's alliance systems and its plans for national missile defence (Goldstein and Kozyrev 2006: 168-9). Moreover, both countries maintain very close relationship with Venezuela, not to mention China's refusal to cooperate, and Russia's silence with regards to human rights issues in Sudan and Myanmar. Finally, both countries resent foreign criticism of their domestic human rights records, and outside meddling in what they see as illegitimate separatism in Chechnya and Taiwan.

Russia and China share an interest with many other non-Western countries, including Venezuela and Iran, in ensuring a multipolar world as opposed to a unipolar world dominated by the United States. It is important to note that despite the existence of the SCO, and the Sino-Russian axis, the subgroup is not linked through formal treaties or organizations. However, their informal alliance is observed through increasing political and economic cooperation and behaviour which undermines the norms underlying the Western-dominated capitalist system. Below, I examine how the China-led subgroup suboptimizes at the expense of the larger group.

\section{China's neo-mercantilism and resource nationalism in energy markets}

In recent years, China's "continuing economic growth has been threatened by the shortage of energy supplies," and this issue has thus drawn much political attention in Beijing, especially since "energy shortages in China can choke its economy and lead to a serious economic slowdown" (Xu 2006: 268 and 271). This would, in turn, expose the CCP to inherent domestic vulnerabilities. In order to continue fuelling its economic growth, and thus to preserve domestic regime 
stability, it is paramount for China to secure the access to ever increasing amounts of imported oil. Accordingly, China has employed various neomercantilist methods, as its national oil companies (NOCs) operate in ways which OECD countries have spent decades working to prohibit (Rosen and Houser 2007: 41). At a minimum, statist initiatives to secure hydrocarbon resources in foreign countries - with an attendant willingness toward corruption, ignoring human rights issues, offering soft loans, and making investments in unrelated sectors and infrastructure projects as part of these initiatives undercut OECD standards for export financing and other good-governance criteria. China's neo-mercantilist behaviour in the energy markets challenges the rules-based international order for trade and investment in energy that the United States had long championed, and which is based on US-designed market arrangements and US-designed and sponsored institutions.

China's NOCs are not 'constrained' by having to earn profits (Assis et al 2005), and are backed by the Chinese government, both financially and politically, in order to advance national policies. When an SOE steps out on the world stage, it does so with many critical and often quiet advantages, from diplomatic support to soft government loans, which it pays for by advancing the state's agenda (Mitchell and Lahn 2007). In their quest for oil, supportive government policies are crucial in winning or losing in overseas bidding and negotiations. China, through its NOCs - CNPC, Sinopec and CNOOC - is spending billions of dollars on a global scramble for oil to feed its booming economy. Chinese NOCs have the ability to obtain government loans at little or no interest, and this is often accompanied by soft government loans to energy-rich governments. China's NOCs have acquired growing equity oil stakes and long-term crude oil contracts, and have signed 'strategic' alliances in many regions of the world. In doing so, they have emerged victorious vis-à-vis major Western IOCs in bidding and negotiations, and by not following the 'rules of the game' have provided Western IOCs with unfair and unwanted competition in the Middle East, Central Asia, Russia, Latin America and Africa.

Chinese NOCs' success is bolstered by the fact that in general, oil importing countries' NOCs are often favoured by host governments (Marcel 2006: 71; Mitchell and Lahn 2007: 9). For example, many host governments, such as Sudan, Myanmar, Iran, are attracted by the fact that China's government agencies and financial institutions do not apply conditions, such as the UN Global Compact, regarding transparency and external monitoring of operations affecting human rights and ethical issues to loans and aid packages associated with oil deals (Chen 2007: 41-54; Mitchell and Lahn 2007: 9). Therefore, China's NOCs are 
clearly advantaged vis-à-vis major Western IOCs in their dealings with host governments.

Western IOCs' competition for investment in untapped energy deposits with China's NOCs is fiercer than ever (Bozon et al 2005). Boosted by the availability of alternative investment options provided by Chinese NOCs, countries all around the non-Western world, which had reluctantly ceded ground to Western IOCs in the wake of globalization in the 1990s, seem to be reclaiming lost ground. The openness to foreign direct investment (FDI) in Latin America in the 1990s generated enough resentment to swing the pendulum in the other direction. Whereas MNCs in general were offered subsidies and tax cuts to invest in Latin American economies in the 1990s, and here note one percent royalties paid by Western IOCs producing in Venezuela's Orinoco Tar Sands, these generous terms are now being eliminated, and governments are increasingly regulating their politically sensitive industries. In the current decade, Venezuela's President Hugo Chàvez has marginalized the private sector by changing Venezuela's hydrocarbon legislation, and various energy projects in Venezuela recently fell under the state control. Russia, a transition economy, has like other transition economies, very little experience with inward FDI. In the 1990s, following the collapse of Communism, Russia's economy was open for investment, then an important component of the economic reform program. Its initial openness, evident in pro-FDI policies and privatization, was just the calm before the storm, which started with Putin's crackdown on Yukos in mid-2003. What followed was a 're-nationalization' of much of Russia's oil industry, increased regulation and higher taxes, or in other words, an increasingly anti-FDI climate. Russia retreated from liberalization and returned to high levels of state control. By understanding how important it is for a developing, transition economy to control its oil industry as relying on global market forces alone did not serve Russia's interests, it has quickly learnt how to deal with the presence of MNCs, and Western IOCs in particular. Putin also understands that the goals and interests of these MNCs mainly do not coincide with Russia's, and thus the door is now closed for any major Western IOC participation in its oil industry. Thus far, Putin has largely accomplished his goal of re-nationalizing hydrocarbons resources, and legislation introduced in 2005 makes foreign investment in the country's most geologically attractive areas much more difficult.

This resurgence of resource nationalism is not confined to Russia and Venezuela, but is evident elsewhere in Latin America and the former Soviet Union, and also in the Middle East and Africa. As argued above, Chinese NOCs are present in all of these regions. Overall, there is a seesaw of power balance between 
governments and firms, determined by the particular circumstances of the times. In current decade, when considering exclusively empirical evidence from the oil and gas industry, the nation state is a robust regulator of FDI, and the world is witnessing a resurgence of resource nationalism. In the first decade of the new millennium governments are not fading away in the face of the power of Western IOCs. On the contrary, bargaining power of Western IOCs is fading away vis-à-vis that of non-Western host governments and Chinese NOCs, and this may result in the eventual decline of the 'Big Oil' companies (Bozon et al 2005), some of the largest and most profitable companies in the Westerndominated capitalist system.

Generally, the view held by many globalization scholars in the 1990s was that some form of fundamental technological shift has been taking place that enhances the power of MNCs against the state (Risse-Kappan 1995; Held et al 1999). It has particularly been apparent in the argument that technological change has increased the power of mobile capital (MNCs) vis-à-vis immobile actors (states) in general (Cerny 1995; Korten 1995; Ohmae 1995; George 1999). The core of this argument is that enhanced mobility constitutes a form of 'exit' power for capital agents, providing them with a form of bargaining power. In the present context, it is commonly claimed that mobile MNCs can 'arbitrage' different political and economic jurisdictions, producing a 'race to the bottom' in terms of regulatory policy and the costs of doing business. Although this implicit threat of exit by itself may tend to bias economic policy in favour of business preferences, it is also sometimes held to increase the political 'voice' of international business (Hirschman 1970; Gill 1995). In this view, we ought to see an increase over time in the influence of business over policy. However, as illustrated above, Western IOCs have lost their influence over the host states, and non-Western resource nationalism is rampant. Chinese-led suboptimization within the Western-dominated capitalist system is evident from the overall trends in the energy markets, examined above. Below, it is argued that many non-Western economies have been dominated by SOEs, and this is not exclusive to the oil and gas industry. Thus, the power shift is not restricted to the energy markets, and this is a very significant factor in the subgroup's suboptimization effort.

\section{the rise of SOEs: oil is not the exception}

Stephen Krasner argued that oil was the exception in analyzing which exporters regulate the world market for a major raw material (Krasner 1974). Analysis here differs from Krasner's, as it focuses on examining if oil industry is the only 
industry in which state-owned companies compete with private MNCs, and the argument is that the rise of SOEs goes well beyond the oil and gas industry. Nowadays, SOEs are powerful for a variety of reasons, and in this light, oil is not the exception. SOEs challenge a standard assumption about the future of globalization - that the private sector will be predominant. Accordingly, globalization is no longer a private business affair, and has according to Abdelal and Segal "passed its peak", as in recent years the health of globalization has been damaged by the change in the way both oil exporting and importing states do business (Abdelal and Segal 2007). SOEs are both consolidating control at home and expanding aggressively abroad, in some cases effectively reversing the privatization campaigns first unleashed in the West a quarter century ago. Moreover, countries as diverse as Russia, Venezuela, Singapore, Dubai and China practice variants of the same strategy using a new kind of 'multinational': aggressive SOEs that can leverage their lucrative home-turf advantage to expand overseas.

In the West, the notion that SOEs might thrive in a borderless world market is seldom raised, let alone taken seriously. For example, American suspicion of government ties to business has boiled over repeatedly in 2005 and 2006, forcing a Chinese state-owned oil company, CNOOC, to abandon its bid for UNOCAL, and a Dubai state-owned company to give up newly acquired U.S. port facilities. Even France, one of the most statist economies in Western Europe, is reviving a privatization campaign that had slowed in recent years. Yet, beyond the West, nations are consolidating state ownership of industries as diverse as finance and auto-making, and in some cases using state firms to overtly geopolitical ends. In Russia, where the supplies of the state gas monopoly, Gazprom, have been used as a lever against recalcitrant Eastern European neighbours, President Putin has vowed to retain state control of strategic sectors, particularly energy, and state companies have become the face of the Russian economy. Perhaps the most brazenly political dealmaker is Venezuelan President Hugo Chávez, who has turned Petroleos de Venezuela (PdVSA), the state-owned company, into a financing vehicle for his domestic and regional political ambitions. In addition, Chávez has established close links with China, Russia, Iran, and other nonWestern countries, each of which with economy dominated by SOEs of their own.

The most sophisticated model of state capitalism is Singapore. Its governmentowned investment arm, Temasek, has been drawing fire for buying banks across Asia and precipitating a political crisis in Thailand when it acquired former Prime Minister Thaksin Shinawatra's family-owned telecommunications empire 
for $\$ 1.9$ billion. Temasek played a key role in building many of Singapore's most famous international brands, including Singapore Airlines and Singapore Telecom (SingTel). It still controls seven of the country's ten biggest publicly listed companies and a portfolio worth an estimated $\$ 65$ to $\$ 70$ billion - or 34 percent of the value of all shares traded on the local exchange - as a major institutional investor. Recently, government capital, through Temasek, has been directed into areas the state considers strategically important. In March 2006, for example, Temasek sold a $\$ 1.25$ billion stake in SingTel to fund expansion overseas. Outside of the oil industry, Temasek is a revealing window into SOE competitiveness with the private sector. Since 2003, it has created a formidable banking empire that stretches from Seoul through Mumbai to London. Together, its stakes in 12 overseas banks are worth $\$ 20$ billion, and it has invested even more in telecommunications, ports, airlines and pharmaceuticals (Temasek 2006). Temasek's returns run well below global stock-market averages, as for all the success of its stars, like Singapore Airlines and SingTel, Temasek also continues to support firms like Chartered Semiconductor, which is in deep debt and has lost 90 percent of its share value since 1999, since government is unwilling to sack 4,000 Singaporeans. This shows that Temasek, as many NOCs, is not guided exclusively by profit maximization but also by governmental prerogatives.

To reiterate, when SOEs step out on the world stage, they do so with many critical tacit advantages: from diplomatic support to soft government loans. These are repaid by advancing the home state's agenda. Consider Emirates, one of the world's most profitable airlines. The airline was launched to further Dubai's ambition to become a regional hub, and attributes its own growth to Dubai's. It plans to double the size of its fleet to more than 250, including the largest order for Airbus's new double-decker super jumbo A380, which costs an estimated \$250 million per plane. That is the kind of colossal financial gamble that is much easier to make with backing from a government treasury.

China's SOEs are not only expanding aggressively abroad by employing various neo-mercantilist methods, but are also consolidating at home. Ever since Deng Xiaoping drove China onto the capitalist road in 1978, foreigners have poured in, assuming the economy would ultimately end up in private hands. However, Beijing never declared such intentions, and with each passing year under $\mathrm{Hu}$ Jintao it becomes more apparent that China is not in transition to a privately owned economy. While foreign firms are lining up to invest in China, Beijing seems increasingly reluctant to let them in, as several recent acquisitions of large Chinese firms by foreign companies have been stalled after a storm of public protest over the impact such sales could have on China's economic security 
Bremner and Roberts 2006: 42). What the leadership refers to, as 'Socialism with Chinese Characteristics' is a sustainable and competitive hybrid form of state capitalism. By some estimates, government-linked companies account for half of China's GDP and much of its dynamism (Wehrfritz 2006: 42). Meanwhile, the private sector accounts for no more than 30 percent of the economy (Pei 2006: 35). All but one of Chinese firms that rank among the world's top 2,000 companies, according to Forbes, has ties to the government (Forbes 2006: 51-9), and of the 1,600 companies listed on the country's domestic stock exchanges, fewer than 50 are private (Pei 2006: 35; Wehrfritz 2006: 42). Contrary to conventional wisdom, China's state sector continues to grow, while the local private sector struggles. According to Pei (2006: 35):

\begin{abstract}
the state remains ... securely in control of the "commanding heights" of the economy: It is either a monopolist or a dominant player in the most important sectors, including financial services, banking, telecommunications, energy, steel, automobiles, natural resources, and transportation.
\end{abstract}

This state of affairs is not about to change. In August 2006, Beijing introduced measures to require government review of mergers and acquisitions that could affect China's 'economic security' or that involve 'key industries' or popular domestic trademarks. Moreover, a new antimonopoly law primarily targets multinationals that the Chinese government believes have too much market power, and since November 2005, domestic companies receive superior tax and regulatory treatment to their foreign counterparts (Abdelal and Segal 2007: 110). Rather than a genuine opening to global competition, Beijing's real agenda since the late 1990s has been 'corporatization', or creating state giants that can compete with Western MNCs. Besides consolidating its oil businesses into a handful of large companies capable of pooling technical resources and competing directly with the largest Western IOCs, Beijing is using its assets to build state-run conglomerates that dominate every sector it considers strategic, from petrochemicals, power generation, auto-making, aviation, to steel, mining and finance.

One can conclude that oil and gas industry is not the only industry in which SOEs successfully compete with Western MNCs. SOEs are consolidating at home and abroad the very same sectors that were the original targets of privatization when the neoliberal revolution began under Ronald Reagan and Margaret Thatcher. SOE purchases are bricks-and-mortar and Old Economy - mature businesses with relatively low returns on investment. They focus on basic infrastructure that supports global commerce, including ports, refineries, airlines, 
telecoms and financial services. Overall, their recent success negates the common Western assumption that in the future, the private sector will be predominant. Globalization is decreasingly a private business affair.

\section{discussion}

As argued above, the subgroup's suboptimization is evident in China's strategy of competing for access to, and control of, hydrocarbon resources, which challenges the rules-based international order for trade and investment, in resource nationalism in various non-Western energy producing and exporting states, and in the general rise of SOEs in many non-Western countries, which challenge the future dominance of the private sector. China's and many other non-Western states' recent behaviour in the international system challenges the rules-based international order for trade and investment that the West had long controlled, and which is based on US-designed market arrangements and USdesigned and sponsored institutions. The tenets of neoliberalism and Washington Consensus are facing a direct systemic challenge from the subgroup's alternative model. This alternative capitalist model is preferred by many non-Western authoritarian and currently rule-taking regimes, which might in future undermine existing economic and political order.

The non-Western subgroup's suboptimization within the Western-dominated capitalist system is characterized by the Chinese strategy of competing for access to, and control of, hydrocarbon resources, as China's actions in the energy markets clearly clash with prevailing international norms (Gilley 2004: 51). Although some experts argue that "China has behaved like a normal player in the international energy market, buying as much oil as it can and investing in as many places as it can afford" (Xu 2006: 265), if China's neo-mercantilist behaviour is the norm nowadays, other countries should behave accordingly or face serious problems in future. From recent developments, a network of direct bilateral oil deals between NOCs in exporting and importing countries, often associated with 'no strings attached' soft government loans and subversion of human rights issues may gradually displace essentially economic competition among firms in international markets. Elements of China's forays into Africa, the Middle East, Central Asia, and Latin America have something of this character. China's increasing reliance on neo-mercantilist strategies to secure access to hydrocarbon resources, rather than relying solely on international markets to meet their energy needs, challenges the rules-based international order for trade and investment. 
Current Chinese strategic thinking is characterized by the view that, as China engages and does business with any and all countries in the world, it is building a store of goodwill that may in future weaken US hegemony (Yang 2006). A strategy of building commercial relationships with many non-Western countries can be just as effective as military competition in thwarting US dominance in key regions such as the Middle East. As countries in the region, such as Iran, stand up on their own to US pressure, they feel secure in the knowledge of continued access to Chinese markets, and Chinese political support, should their relations with the US escalate even further. Such 'foreign policy by proxy' is a strategy with deep roots in Chinese history and culture. To be able to achieve foreign policy objectives without direct, public action is the highest form of statecraft (Keefer Douglas et al 2006: 20).

While Washington is preoccupied with fighting the 'long war', avoiding policy failure in Iraq and cheering the 'forward march of freedom', the political consequences of recent structural shifts in global energy markets are posing the most profound challenge to the Western-dominated global capitalist system since the end of the Cold War. The increasing control that NOCs exercise over the world's reserves of crude oil and natural gas is, under current market conditions, enabling some energy exporters to act with escalating boldness against American and other Western countries' interests and policies. Perhaps the immediate examples are Venezuela, Russia, and Iran. Venezuela's efforts to undermine US influence in Latin America, Russia's willingness to use its newfound external leverage to further its national interests, and Iran's tacit use of its 'oil weapon' to pursue nuclear technology, have all, to an extent, been enabled by China's stateorchestrated strategy to 'secure' access to oil around the world.

The implications of recent structural shifts in global energy markets for America's international influence are illustrated by the way these forces are frustrating US objectives on the Iranian nuclear issue and in limiting Chàvez's attempted spread of 'Bolivarian Revolution' around Latin America. The policies of key players on the Iranian nuclear issue are conditioned far more by calculations about the economics and geopolitics of oil than was the case during the run-up to the Iraq War in 2003. As the Western powers consider what sort of action against Iran they might collectively support, it is clear that their options in the UN Security Council are severely limited by Russian and Chinese resistance to the imposition of comprehensive sanctions or other strongly punitive measures (Garver 2006; Howard 2007). The United States have thus far been unable to prevent Hugo Chàvez from luring other Latin American regimes by offering them subsidized energy for their political support. Tight oil markets, 
evident in current high oil prices, and the availability of new markets (China and India) have endowed Chàvez with regime stability from outside (the United States) and inside (coup) threats.

The US and its allies today face radicals like Chávez and Ahmadinejad who have the will, savvy, resources and support (from China and Russia) to constrain American power and thwart Western interests. Many developing countries, and China certainly one of them, regard trade as "a mercantilist zero-sum game," in which "the West is bent on stopping [them] from winning it" (Norberg 2006: 48). This is not surprising when one considers US Congress' blocking of CNOOC's purchase of UNOCAL. In such a zero-sum game, oil producers and exporters, such as Russia, Venezuela and Iran, together with China, Singapore, or the UAE, countries that nurture their own SOEs, are increasing their own gains by suboptimizing within the Western-dominated global capitalist system. Eventually, this may result in direct competition between the predominant neoliberal Western paradigm based on the Washington Consensus, which is synonymous with globalization, and which has entered into a structural crisis, and the emerging non-Western economic and political capitalist model, based on the Beijing Consensus - authoritarianism, political stability before reforms and freedom, welfare society, state ownership of key sectors, strong state control over capital allocation, powerful regulation of foreign and domestic investment and international trade (Cooper Ramo 2004; Hutton 2006; Lieberthal 2006; Möller 2006; Teo 2006; Peerenboom 2007). This model is more appealing to developing countries, especially when considering the failure of neoliberal model in improving prosperity in many former Soviet Union and Latin American countries (Cooper Ramo 2004; Li 2005). For example, some have suggested that Russia's recent tilt toward authoritarianism reflects the influence of China's model of 'markets without democracy', centred around Beijing Consensus (Bernstam and Rabushka 2002). In 1992, Francis Fukuyama suggested that "despite the apparent absence of systematic alternatives to liberal democracy at present, some new authoritarian alternatives, perhaps never before seen in history, may assert themselves in the future" (Fukuyama 1992: 235). The Beijing Consensus may be one such alternative, and after all, the history may not have reached its end.

\section{conclusion}

Overall, I am not arguing that China is not a part of the Western-dominated capitalist system. It certainly is. Its economic growth is highly dependent on sales of its cheap products in Western economies, and has, since 2002, been the largest 
receiver of FDI. Likewise, non-Western energy producing and exporting countries are equally part of that system. Much of their oil and gas goes to the West. Thus, both China and non-Western energy exporters reap enormous benefits from participating in the global capitalist system, and exiting this system is not an option. However, despite of the fact that they are an integral part of the system, their actions point to them forming a subgroup within the system and by doing so, improving their wellbeing at the expense of the system as a whole. Whether their suboptimization will one day result in bifurcation or a major systemic change is beyond the scope of this article. To return to the debate on the nature and implications of China's rise, it is clear from the above analysis that China is not a status quo power. The very fact that since 1978 it gradually entered the Western-dominated capitalist system and institutions goes against the very conceptualization of status quo. If it did not join Western-dominated institutions, then it could have been regarded a status quo power. More to the point, since entering the capitalist system, and as evident from the above analysis, as China often failed to act according to 'the rules of the game', Western-dominated capitalist system has been undermined as a consequence of China's actions. As shown above, it is far from being the only culprit. While China may not be hard balancing against the United States, soft balancing is clearly an element in the subgroup's suboptimization.

[1] For an overview of 'China threat' issue, see Herbert Yee, and Ian Storey (eds), 2002. The China Threat: Perceptions, Myths and Reality (London: RoutledgeCurzon).

Abdelal, Rawi, and Adam Segal, 2007. 'Has Globalization Passed Its Peak?', Foreign Affairs, 86(1): 103-14.

Acharya, Amitav, 2003/04. 'Will Asia's Past Be Its Future?', International Security, 28(3): 152.

Arrighi, Giovanni, 1994. The Long Twentieth Century (London: Verso).

Art, Robert J., 2005/06. 'Correspondence: Striking the Balance', International Security, 30(3): 177-85.

Assis, Vicente F., Bernard Minkow, and André Olinto, 2005. 'National Oil Companies: The Right Way to Go Abroad', The McKinsey Quarterly.

Bergsten, C. Fred, Bates Gill, Nicholas R. Lardy, and Derek Mitchell, 2006. China: The Balance Sheet (New York: Public Affairs).

Bernstam, Michael, and Alvin Rabushka, 2002. 'Beijing Consensus for Russia?' Hoover Institution Public Policy Enquiry, Russian Economy. 
Bernstein, Richard, and Ross Munro, 1997. The Coming Conflict with China (New York: Alfred A. Knopf).

Blagov, Sergei. 2003. 'More Russian Weapons Go to China', Asia Times, 30 January.

Bozon, Ivo J. H., Stephen J. D. Hall, and Svein Harald Øygard, 2005. 'What's Next for Big Oil?', The McKinsey Quarterly (2).

Bremner, Brian, and Dexter Roberts, 2006. 'How Beijing is Keeping Banks at Bay', Business Week, 2 October.

Brooks, Stephen G., and William C. Wohlforth, 2005/06. 'Correspondence: Striking the Balance', International Security, 30(3): 186-91. 2005. 'Hard Times for Soft Balancing', International Security, 30(1): 72-108.

Calder, Kent E., 1996. Asia's Deadly Triangle: How Arms, Energy and Growth Threaten to Destabilize Asia-Pacific (London: Nicholas Bealey Publishing).

Cerny, Philip G., 1995. 'Globalization and the Changing Logic of Collective Action', International Organization, 49: 595-625.

Chen, Matthew E., 2007. 'Chinese National Oil Companies and Human Rights', Orbis.

Christensen, Thomas J., 2006. 'Fostering Stability or Creating a Monster? The Rise of China and U.S. Policy toward East Asia', International Security, 31(1): 122-3.

Cohen, Warren I., 2006. 'China's Power Paradox', The National Interest.

Cooper Ramo, Joshua, 2004. Beijing Consensus: Notes on the New Physics of Chinese Power (London: Foreign Policy Centre).

Feigenbaum, Evan A., 2001. 'China's Challenge to Pax Americana', Washington Quarterly, 24(3): 31-43.

Foot, Rosemary, 2006. 'Chinese Strategies in a US-Hegemonic Global Order: Accommodating and Hedging', International Affairs, 81(1): 77-94.

Forbes, 2006. 'The Forbes Global 2000: The World's Biggest Public Companies', 17 April.

Fukuyama, Francis, 1992. The End of History and the Last Man (London: Penguin).

Garver, John W., 2006. China \& Iran: Ancient Partners in a Post-imperial World

(Seattle: University of Washington Press).

George, Susan, 1999. 'State Sovereignty Under Threat', Le Monde Diplomatique.

Gertz, Bill, 2000. The China Threat: How the People's Republic Targets America (Washington, D.C.: Regnery).

Gill, Bates, and Yanzhong Huang, 2006. 'Sources and Limits of Chinese "Soft Power"', Survival, 48(2): 17-36.

Gill, Stephen, 1995. 'Globalization, Market Civilization, and Disciplinary

Neoliberalism', Millennium, 24: 399-423.

Gilley, Bruce, 2004. China's Democratic Future: How It Will Happen and Where It 
Will Lead (New York: Columbia University Press).

Gilpin, Robert, 1981. War and Change in World Politics (Cambridge: Cambridge University Press).

Goh, Evelyn, 2005. 'Meeting the China Challenge: The US in Southeast Asian Regional Security Strategies', Policy Studies 16, Washington, D.C., EastWest Center.

Goldstein, Avery, 2005. Rising to the Challenge: China's Grand Strategy and International Security (Stanford: Stanford University Press).

Goldstein, Lyle, and Vitaly Kozyrev, 2006. 'China, Japan and the Scramble for Siberia', Survival, 48(1): 168-9.

Guo, Sujian (ed), 2006. China's "Peaceful Rise" in the 21 ${ }^{\text {st }}$ Century: Domestic and International Conditions (Aldershot: Ashgate).

Hays Gries, Peter, 2005. 'China Eyes the Hegemon', Orbis, 49(3).

Held, David, Anthony McGrew, David Goldblatt, and Jonathan Perraton, 1999. Global Transformations (Cambridge: Polity).

Hirschman, Albert O., 1970. Exit, Voice and Loyalty: Responses to Decline in Firms, Organizations, and States (Cambridge: Harvard University Press).

Howard, Roger, 2007. Iran Oil: The New Middle East Challenge to America (London: I.B. Tauris).

Hutton, Will, 2006. The Writing on the Wall: China and the West in the 21 ${ }^{\text {st }}$ Century (London: Little, Brown).

Ikenberry, G. John (ed), 2002. America Unrivalled: The Future of the Balance of Power (Ithaca: Cornell University Press). 1999. 'America's Liberal Hegemony', Current History.

Johnston, Alastair Iain, 2003. 'Is China a Status Quo Power?', International Security, 27(4): 5-56.

Kapstein, Ethan B. and Michael Mastanduno (eds.), 1999. Unipolar Politics: Realism and State Strategies after the Cold War (New York: Columbia University Press).

Keefer Douglas, John, Matthew B. Nelson, and Kevin Schwartz, 2006. 'Fueling the Dragon's Flame: How China's Energy Demands Affect Its Relationships in the Middle East', in U.S.-China Economic and Security Review Commission, 14 September.

Korten, David, 1995. When Corporations Rule the World (San Francisco: BerrettKoehler).

Krasner, Stephen D., 1974. 'Oil is the Exception', Foreign Policy, 14: 68-84.

Kristof, Nicholas, 1993. 'The Rise of China', Foreign Affairs.

Kurlantzick, Joshua, 2007. Charm Offensive: How China's Soft Power Is Transforming the World (New Haven: Yale University Press).

Leverett, Flynt, and Pierre Noël, 2006, 'The New Axis of Oil', The National 
Interest, 84: 65.

Li, Minqi, 2005. 'The Rise of China and the Demise of the Capitalist WorldEconomy: Exploring Historical Possibilities in the $21^{\text {st }}$ Century', Science $\mathcal{E}$ Society, 69(3): 420-48.

Lieber, Keir A., and Gerard Alexander, 2005/06. 'Correspondence: Striking the Balance', International Security, 30(3): 191-6.

_Waiting for Balancing: Why the World Is Not Pushing Back', International Security 30(1).

Lieberthal, Kenneth, 2006. 'Why the US Malaise Over China?', YaleGlobal, 19 January.

Marcel, Valérie, 2006. Oil Titans: National Oil Companies in the Middle East (London: Chatham House).

Mearsheimer, John, 2001. The Tragedy of Great Power Politics (New York: W.W. Norton).

Medeiros, Evan S., 2005/06. 'Strategic Hedging and the Future of Asia-Pacific Stability', Washington Quarterly, 29(1): 145-67.

Mitchell, John V., and Glada Lahn, 2007. 'Oil for Asia', Chatham House, Energy, Environment and Development Programme, Briefing Paper 07/01, March.

Möller, Kay, 2006. 'The Beijing Bluff', Survival, 48(2): 137-46.

$\mathrm{Ng}$, Ka Po, 2006. 'Critical Developments in Chinese Politics', in Czeslaw Tubilewicz (ed), Critical Issues in Contemporary China (London: Routledge), 44.

Norberg, Johan, 2006. 'China Paranoia Derails Free Trade', Far Eastern Economic Review.

Ohmae, Kenichi, 1995. The End of the Nation State (New York: Free Press).

Pape, Robert A., 2005. 'Soft Balancing against the United States', International Security, 30(1): 7-45.

Paul, T.V., 2005. 'Soft Balancing in the Age of U.S. Primacy', International Security, 30(1): 46-71.

Peerenboom, Randall, 2007. China Modernizes: Threat to the West or Model for the Rest? (Oxford: Oxford University Press).

Pei, Minxin, 2006. 'The Dark Side of China's Rise', Foreign Policy.

Qiao, Liang and Wang Xiangshui, 1999. Unrestricted Warfare (Beijing: PLA Literature and Art Publishing House).

Risse-Kappan, Thomas (ed), 1995. Bringing Transnational Relations Back In (Cambridge: Cambridge University Press).

Rosen, Daniel H., and Trevor Houser, 2007. 'China Energy: A Guide for the Perplexed', China Balance Sheet, A Joint Project by the Center for Strategic and International Studies and the Peterson Institute for International Economics, May. 
Ross, Robert S., 2004. 'Bipolarity and Balancing in East Asia' in T.V. Paul, James J. Wirtz, and Michael Fortmann, (eds), Balance of Power: Theory and Practice in the Twenty-first Century (Stanford: Stanford University Press), 267-304.

Shambaugh, David, 2004/05. 'China Engages Asia: Reshaping the Regional Order', International Security, 29(3): 97. 2000. 'Sino-American Strategic Relations: From Partners to Competitors', Survival, 42(1): 97-115.

Song, Qiang, Zhang Zangzang, Qiao Bian, Zhang Xiaobo, Tang Zhengyu, and Gu Qingsheng, 1996. China Can Say No (Beijing: Zhonghua Gongshang Lianhe Chubanshe).

Sutter, Robert, 2004. 'Asia in the Balance: America and China's "Peaceful Rise"', Current History.

2005. China's Rise in Asia: Promises and Perils (New York: Rowman and Littlefield).

Swaine, Michael D., 2005. 'Chinese Crisis Management: Framework for Analysis, Tentative Observations, and Questions for the Future', in Andrew Scobell and Larry M. Wortzel (eds), Chinese National Decisionmaking Under Stress (Washington, D.C.: Strategic Studies Institute), 23.

'Temasek Holdings - Temasek-Linked Companies', $<\underline{\text { http://www.temasekholdings.com.sg/our investments/linked companies }}$ .htm> (accessed 7 June 2006).

Teo Chu Cheow, Eric, 2006. 'U.S.-China Ideological Rivalry Heats Up', The Japan Times, 6 January.

Timperlake, Edward, and William C. Triplett, II, 1999. Red Dragon Rising: Communist China's Military Threat to the United States (Washington, D.C.: Regnery).

Trenin, Dmitri, 2006. 'Russia Leaves the West', Foreign Affairs, 85(4): 87-96. 2003. 'Southern Watch: Russia's Policy in Central Asia', Journal of International Affairs, 56(2): 119-31.

Van Ness, Peter, 2002. 'Hegemony, not Anarchy: Why China and Japan are not Balancing US Unipolar Power', International Relations of the Asia-Pacific, 2: 131-50.

Wallerstein, Immanuel, 1995. After Liberalism (New York: The New Press). 1979. The Capitalist World-Economy (New York: Cambridge University Press).

Walt, Stephen M., 205. Taming American Power: The Global Response to U.S. Primacy (New York: W.W. Norton).

Wang, Jisi, 2005. 'China's Search for Stability with America', Foreign Affairs, 84(5). Wehrfritz, George, 2006. 'The New State Capitalism', Newsweek, 1 May. Wesley, Michael, 2005. 'The Geopolitics of Energy Security in Asia', paper 
presented in Energy Security in the Asia-Pacific conference, Griffith Asia Institute, Brisbane, 31 August-2 September.

Wohlforth, William C., 1999. 'The Stability of a Unipolar World', International Security, 24(1): 5-41.

Xu Yi-Chong, 2006. 'China's Energy Security', Australian Journal of International Affairs, 60(2): 268, 271.

Yahuda, Michael B., 2005. The International Politics of the Asia Pacific, $2^{\text {nd }} \mathrm{ed}$. (London: Routledge).

Yang, Yi, 2006. 'A Period of Strategic Opportunities for Chinese National Security', Education and Research (Jiaoxue yu yanjiu).

Yee, Herbert, and Ian Storey (eds), 2002. The China Threat: Perceptions, Myths and Reality (London: RoutledgeCurzon).

Zheng, Bijian, 2005. 'China's "Peaceful Rise" to Great-Power Status', Foreign Affairs.

Zhu, Zhiqun, 2006. US-China Relations in the $21^{\text {st }}$ Century: Power Transition and Peace (London: Routledge). 